\title{
INTERNATIONALIZATION AS A STRATEGIC DIMENSION FOR THE DEVELOPMENT OF ACADEMIC INSTITUTIONS
}

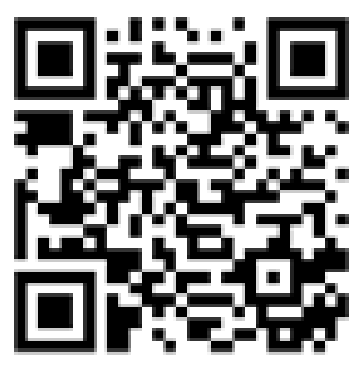

To cite this article:

\author{
Vasyl Kremen, Dr. Sc., Prof. \\ President, \\ National Academy of Educational Sciences of Ukraine \\ Kyiv, Ukraine \\ president@naps.gov.ua \\ https://orcid.org/0000-0001-5459-1318
}

\author{
Sergiy Kurbatov, Dr. Sc., Senior Researcher \\ Adviser to Presidium, \\ National Academy of Educational Sciences of Ukraine \\ Kyiv, Ukraine \\ sergiy.kurbatov@gmail.com \\ https://orcid.org/0000-0002-8929-7562
}

Kremen, V., \& Kurbatov, S. (2021). Internationalization as a strategic dimension for the development of academic institutions. Education: Modern Discourses, (4), 6-12.

https://doi.org/10.37472/2617-3107-2021-4-01

\begin{abstract}
The paper is devoted to the analyses of specific features of internationalization of academic research institutions, first of all at National Academy of Educational Sciences (NAES) of Ukraine. We conducted a brief observation of contemporary English language literature in the area of internationalization of academic institutions and evaluation of its effectiveness. We tried to analyze the situation with internationalization at academic institutions in situation of limited financial support and restrictions, connected with pandemic situation with COVID-19. Special stress was made on elaboration and implementation of successful strategy of internationalization with realistic, accurate and measurable dimensions of internationalization. Using as an example the Strategy of Internationalization of NAES of Ukraine, which was approved by the Presidium of NAES of Ukraine on March, 18, 2021, we observed the main dimensions of internationalization with the relevant indicators, which could be implemented in other academic institutions in Ukraine. Also, we compare some of these indicators with the indicators of internationalization at leading international university rankings (QS and THE).

Keywords: internationalization, strategy of internationalization, indicator, academic institution, international university rankings, National Academy of Educational Sciences of Ukraine.
\end{abstract}

\section{INTRODUCTION, PROBLEM STATEMENT}

Internationalization is an essential component of mission of contemporary universities and other academic institutions (Scott, 2006). During last few decades it became a popular object of different researches and legitimized itself as an important dimension of institutional 
development. At the same time the term "internationalization" became much more complicated. Different aspects of internationalization need to be identified and to be analyzed. As Jane Knight, the author of one of the most popular definition of internationalization, mentioned:

"As internationalization matures, it is becoming a more important and complex process. Yet, it is also becoming a more confused and misunderstood concept. Internationalization is definitely past the "new flavor of the month" stage. It is firmly embedded in institutional mission statements, policies, and strategies as well as national policy frameworks. This signals that internationalization has come of age and is a legitimate area of policy, practice, and research in higher education" (Knight, 2011).

So, the goal of our research is to analyze the main approaches to internationalization of academic institutions, which are presented in contemporary English language literature and to propose the optimal forms of their implementation in Ukraine, based on current experience of the National Academy of Educational Sciences (NAES) of Ukraine, the leading national institution, which provides theoretical and methodological support of teaching and learning processes at all levels of education, and its strategy of internationalization, which was approved by the Presidium of NAES of Ukraine on March, 18, 2021. In our previous paper we claimed that internationalization of the academic publications, increasing of fundraising activities, especially among foreign and international donors' organizations and increasing the level of academic mobility among researchers and PhD students as main tasks for future development of NAES of Ukraine (Kremen \& Kubatov, 2019).

\section{LITERATURE REVIEW}

The number of publications, devoted to internationalization in academic area, which appeared during last decades, is really impressive. Anna Kosmützky and Rahul Putty for their systematic review, which was published in 2016, identified about 2000 sources, which investigated internationalization in the area of higher education (Kosmützky \& Putty, 2016). Also, researchers processing huge amount of data in order to understand different aspects of internationalization - for example, for investigation of the influence of internationalization on educational programs Mike Zapp and Julia Lerch analyzed 442,283 study programs from 17,129 universities in 183 countries. As a result, they identified three variants of such influence: 1) an interstate model (prevalent in business and political science), 2) a regional model (in political science and law), and 3) a global model (in development studies and natural sciences) (Zapp \& Lerch, 2020),

The classical definition of internationalization in academic area as "the process of integrating an international, intercultural, or global dimension into the purpose, functions or delivery of postsecondary education" was provided by Jane Knight (Knight, 2003). Later she clarified this definition (Knight, 2004; Knight, 2011). Also, it is popular to define internationalization of higher education as a kind of response to the general processes of globalization (Stromquist, 2007).

Internationalization of higher education is an object of researches of such prominent contemporary experts as Philip Altbach (Altbach \& Knight, 2007; Altbach, 2013) and Hans de Wit (de Wit, 2019; de Wit \& Deca, 2020). Special analyses of internationalization of research and contemporary approaches for measurement of this dimension of academic activities were presented in paper "Internationalization of research: Key considerations and concerns" (Woldegiyorgis, Proctor, \& de Wit, 2018). The attempt to identify optimal indicators for evaluation of internationalization in higher education is presented in research paper "A set of indicators 
for measuring and comparing university internationalization performance across national boundaries" (Y Gao, 2018). We need to mention the contribution of Ukrainian researchers from NAES of Ukraine in the investigation of the internationalization of higher education especially the book of Maria Debych "Theoretical background of internationalization of higher education: foreign experience" (Debych, 2019).

The COVID-19 pandemic caused an unpredictable challenge to internationalization of academic institutions. As Philip Altbach and Hans de Wit observed: "The corona virus crisis is upending higher education - as well as economies and the lives of millions of individuals around the world. Universities closed, with teaching canceled or put online. Conferences have been called off. Of direct relevance to international higher education, prospective students have been unable to take examinations, and international students have been unable to travel to their campuses or to return home. Study abroad programs have been canceled. Faculty members have been asked not to travel to affected countries-or to avoid foreign travel entirely" (Altbach \& de Wit, 2020).

In this situation we could observe the diversification of the notion of internationalization of academic institutions. For example, Jenna Mittelmeier and her colleagues recently argued that they identified the third dimension of internationalization - "Internationalization at a Distance" (together with "Internationalization Abroad" and "Internationalization at Home") (Mittelmeier, Rienties, Gunter, \& Raghuram, 2020). "We have conceptualized a new third category of university internationalization-IaD-which outlines the importance of technologyenabled learning across geographic boundaries "abroad" while students simultaneously remain at "home," - claimed the researchers (Mittelmeier, Rienties, Gunter, \& Raghuram, 2020).

\section{METHODOLOGY}

In our paper we analyzed the discourse of internationalization of academic institutions in contemporary literature, with special stress on English language literature. Based on casestudy of current situation and the main ways of enhancement of international activities at NAES of Ukraine, we tried to identify the optimal dimensions and indicators for successful international development of Ukrainian, and wider, post-soviet academic institution in situation of limited financial support and restrictions, connected with pandemic situation with COVID-19. Special stress was made on elaboration of effective strategy of internationalization and its successful implementation.

\section{MAIN RESULTS}

It is impossible to imagine contemporary academic institution without effective international cooperation and real integration in global research structures. In case of Ukraine integration in European research area as "the ambition to create a single, borderless market for research, innovation and technology" (European research area, 2021) is also crucial. Since its establishing, international dimension was essential part of the activities of NAES of Ukraine. But especially important this dimension became after 2014, when integration in European and Euro-Atlantic structures was claimed as a strategic priority for development of Ukraine. This substantial place of internationalization is reflected in main normative documents, which regulate the activities of NAES of Ukraine - in the Statute of NAES (for example, articles 7, 8, 25) (Statute of NAES, 2008) and the Strategy of Development of NAES of Ukraine for 20162022 (for example, subdivision 2.4.1)(Strategy for Development of NAES of Ukraine for 20162022, 2016). 
The effective development of international activities of NAES of Ukraine could be proved by the data from NAES of Ukraine report on the state of using the funds for research activities and the results received in 2020: "In 2020 scientific units of NAES of Ukraine participated actively in realization of about 40 international scientific and educational projects as far as programs of American Councils for International Education, British Council in Ukraine, European Union, United Nations in Ukraine, DVV International in Ukraine, Council of Europe, World Bank, UNESCO, UNICEF and other organizations and foundations. We had continuation of cooperation with 36 foreign members of NAES of Ukraine, who represent 11 countries. We cooperated with scientific and educational institutions from Austria, Belarus, Bulgaria, Canada, China, Finland, France, Germany, Israel, Japan, South Korea, USA, UK and other countries in the framework of 29 agreements about cooperation, which were signed by NAES of Ukraine and hundreds of agreements, were signed by structural units of NAES of Ukraine. Scientific institutions and researchers from NAES of Ukraine work as experts and are the members of more than 50 international organizations" (Kremen, 2021). Also, it is important that during 2020 the representatives of NAES of Ukraine published 330 papers in journals, which are indexed by SCOPUS and Web of Science Core Collection. It is 1,9 times more than in 2019 and 4 times more than in 2018 (Kremen, 2021).

The recent important step in functional regulation and institutional support of internationalization of NAES of Ukraine is connected with the Strategy of Internationalization of NAES of Ukraine for 2021-2025, which was adopted by presidium of NAES of Ukraine on March, 18, 2021. This is: "a document, which regulates the processes of evaluation and development of international activities in the area of educational sciences, pedagogy, and psychology as far as involving researchers, PhD and DSc students in it. The Strategy specifies, expands, and supplements the Strategy of Development of the National Academy of Educational Sciences of Ukraine for 2016-2022, which was adopted at the general meeting of NAES of Ukraine on March 25, 2016. The Strategy aims at increasing the level of internationalization and enhancing the quality of international cooperation in the area of educational sciences, pedagogy, and psychology" (Kurbatov, 2021).

In the Strategy the main dimensions of internalization for NAES of Ukraine were identified. They are: 1) scientific and research cooperation at international level; 2) academic mobility of researchers, $\mathrm{PhD}$ and DSc students; 3) preparation of scientific publications in foreign academic journals and other media; 4) creation of systematic support for "internationalization at home"; 5) strengthening the academic cooperation with foreign members and honorable doctors of NAES of Ukraine; 6) popularization of activities of NAES of Ukraine at international level (Kurbatov, 2021). The restricted financial support of academic activities in our country especially sensitive to academic mobility of researchers, $\mathrm{PhD}$ and DSc students, because majority of academic institutions have no possibilities to support academic visits to other countries. That is why here we totally depend on support of different donors' organizations and foreign partners. Specific dimension of NAES of Ukraine is strengthening the academic cooperation with foreign members and honorable doctors of NAES of Ukraine, who substantially support the promotion of our activities abroad.

It was crucial for NAES of Ukraine to support each dimension of internationalization by transparent and measurable indicators. According to the results of these indicators we could evaluate the level of progress of each academic unit as far as NAES of Ukraine in general. For one of the key dimension of internationalization, scientific and research cooperation at international level, we identified 11 indicators per year: 1) number of foreign academic publications, which were published during last 10 years and are used in each of current research; 
2) number of international grant projects, for which the particular academic unit applied for;

3) number of international grant projects, which received funding; 4) number of researchers, who involved in acting international scientific projects; 5) number of international academic events, which were conducted with foreign financial and/or material support; 6) number of researchers, who speak English and/or other official languages of EU fluently; 7) number of events, conducted for popularization of international and foreign programs of international academic cooperation; 8) number of international and scientific projects, in which academic unit and/or its researchers participated on volunteer basis; 9) number of researchers, who are the members of foreign academies, international scientific societies; 10) number of researchers, who are international experts; 11) amount of foreign financial support per one researcher (Kurbatov, 2021).

We think that these indicators are good tool for evaluation of scientific and research cooperation at international level and provide us with clear picture of dynamics of development in this area. It is much more complicated picture of internationalization than the leading international university rankings provide us. For example, current version of QS University Rankings has only two indicators, which directly evaluate internationalization: 1) international faculty ratio and 2) international student ratio (QS World University Rankings Methodology, 2021). In THE World University Rankings we could find three indicators of internationalization: 1) proportion of international students; 2) proportion of international staff and 3) international collaboration (THE World University Rankings Methodology, 2021).

\section{CONLUSIONS}

So, internationalization of academic institution is crucial for its effective development and overcoming of numerous challenges. A great number of researches in this area show that it is extremely actual topic and the worth object for further investigation. We need to study understanding of internationalization in the Western academic literature and to identify the optimal forms of implementation of the most interesting and perspective of them in practice of Ukrainian academic institutions.

Effective, realistic and measurable strategy of internationalization could be powerful tool for successful development of international activities at academic institutions. The main element of this strategy is identification of the main dimensions of internationalization with the relevant indicators, which could become a valuable background for the monitoring of situation with internationalization at academic institutions and their structural units.

Internationalization became an important dimension of the activities of NAES of Ukraine since its establishing, but especially intensified after 2014. The Strategy of internationalization of NAES of Ukraine with the main dimensions of internationalization with the relevant indicators could be served as an example for elaboration of the similar strategy at other academic institutions. 


\section{REFERENCES}

Altbach, P. G. (Ed.). (2013). The international imperative in higher education. Springer Science \& Business Media. 198 p.

Altbach, P. G., \& de Wit, H. (2020). COVID-19: The internationalisation revolution that isn't. University World News, 14.

Altbach, P. G., \& Knight, J. (2007). The internationalization of higher education: Motivations and realities. Journal of studies in international education, 11(3-4), 290-305.

de Wit, H. (2019). Internationalization in higher education, a critical review. SFU Educational Review, 12(3), 9-17.

de Wit, H., \& Deca, L. (2020). Internationalization of Higher Education, Challenges and Opportunities for the Next Decade. In European Higher Education Area: Challenges for a New Decade (pp. 3-11). Springer, Cham.

Debych M. (2019) Teoretychni zasady internacionalizaciyi vyshhoyi osvity: mizhnarodnyj dosvid: monohrafiya. Nizhyn: PP Lysenko. 408 s.

European reaserch area (2021). Retrieved 2021 from: https://ec.europa.eu/info/research-andinnovation/strategy/strategy-2020-2024/our-digital-future/era_en

Kosmützky, A., \& Putty, R. (2016). Transcending borders and traversing boundaries: A systematic review of the literature on transnational, offshore, cross-border, and borderless higher education. Journal of Studies in International Education, 20(1), 8-33.

Knight, J. (2011). Five myths about internationalization. International higher education, (62). Retrieved 2021 from: https://ejournals.bc.edu/index.php/ihe/article/view/8532

Knight, J (2004). "Internationalization Remodeled: Definition, Approaches, and Rationales". Journal of Studies in International Education. 8, 5-31.

Knight, Jane (2003). Updating the definition of internationalization. International Higher Education, (33). Retrieved 2021 from: https://ejournals.bc.edu/index.php/ihe/article/view/7391

Kremen, V. (2021). NAES of Ukraine report on the state of using the funds for research activities and the results received in 2020: Scientific report at the General Meeting of the National Academy of Educational Sciences of Ukraine, April 9, 2021. Herald of the National Academy of Educational Sciences of Ukraine, 3(1). https://doi.org/10.37472/2707-305X-2021-3-1-1-1

Kremen, V. \& Kurbatov, S. (2019). Transformation of academic life in the $21^{\text {st }}$ century. Education: Modern Discourses, 2. Retrived 2021 from: http://emdnaes.org.ua/index.php/Educ_Mod_ discourse/article/view/55/67

Kurbatov, S. (2021). On Approving the Strategy of Internationalization of the National Academy of Educational Sciences of Ukraine for 2021-2025: Scientific report at the meeting of the Presidium of the National Academy of Educational Sciences of Ukraine, March 18, 2021. Herald of the National Academy of Educational Sciences of Ukraine, 3(1). Retrived 2021 from: https://visnyk.naps.gov.ua/index.php/journal/article/view/132

Mittelmeier, J., Rienties, B., Gunter, A., \& Raghuram, P. (2020). Conceptualizing internationalization at a distance: A "third category" of university internationalization. Journal of Studies in International Education, 25, 3. Retrieved 2021 from: https://journals.sagepub.com/doi/ pdf/10.1177/1028315320906176

QS World University Rankings Methodology (2021). Retrieved 2021 from: https://www. topuniversities.com/qs-world-university-rankings/methodology

Scott, J. C. (2006). The mission of the university: Medieval to postmodern transformations. The journal of higher education, 77(1), 1-39. Retrieved 2021 from: http://geekyartistlibrarian. pbworks.com/f/The\%2Bmission\%2Bof\%2Bthe\%2Buniversity.pdf

Stein, S. (2017). Internationalization for an Uncertain Future: Tensions, Paradoxes, and Possibilities. The Review of Higher Education, 41, 1, 3-32. 
Stromquist, N. P. (2007). Internationalization as a response to globalization: Radical shifts in university environments. Higher Education, 53(1), 81-105.

The Statutes of National Academy of Educational Sciences of Ukraine (2020). Retrieved 2021 from: https://naps.gov.ua/ua/about/statutes/

The Strategy for Development of National Academy of Educational Sciences of Ukraine for 20162022 (2016). Retrieved 2021 from: https://naps.gov.ua/ua/press/announcements/942/

THE World University Rankings: methodology (2021). Retrieved 2021 from: https://www. timeshighereducation.com/world-university-rankings/world-university-rankings-2022methodology

Woldegiyorgis, A. A., Proctor, D., \& de Wit, H. (2018). Internationalization of research: Key considerations and concerns. Journal of Studies in International Education, 22(2), 161-176.

Y Gao (2018). A set of indicators for measuring and comparing university internationalisation performance across national boundaries. Higher Education, 76, 317-366.

Zapp, M. and Lerch, J.C. (2020). Imagining the world: Conceptions and determinants of internationalization in higher education curricula worldwide. Sociology of Education, 93(4), 372-392. 